\title{
TEACHING VISUAL ART IN A MULTICULTURAL SETTING : ATTITUDES, VALUES AND REPRESENTATIONS OF STUDENTS IN ART EDUCATION
}

Mona Trudel, professor

L'École des arts visuels et médiatiques, Université du Québec à Montréal

\section{Introduction}

Are students in art Education at the Université du Québec à Montréal (UQÀM), ready to teach in a multicultural setting? Within the framework of my doctoral studies at Concordia University, Montreal, I have tried to answer this question by studying thirty Bachelor's students in Art Education at the Université du Québec à Montréal.

\section{Context}

Quebec is the only primarily francophone province in Canada. Two linguistic groups exist together there, each with its own educational system: one mainly francophone and Catholic, the other anglophone and Protestant. These two educational networks traditionally received children whose mother tongues were either French or English. After World War II there came a large wave of immigrants whose mother tongue was neither French nor English, a majority of whom chose to send their children to school in English. Let us note that until 1977 Quebec was among the few societies in the world which allowed its population free choice as to the language of schooling. This situation opened access to Anglophone schools for those arriving in Quebec, who preferred to adopt the language of the majority in North America, which for them was associated with prestige and social advancement. It must also be noted that there existed on the part of the francophone and Catholic school system a lack of openness to ethnocultural diversity, which for a long period pushed immigrants toward the Anglophone schools. Thus the multiculturalism of Montreal francophone schools is relatively recent, dating from the end of the 1970's. The large scale arrival of non-francophone children into the francophone school system in Montreal is due to two laws introduced by the Quebec government. Bill 101, adopted in 1977, obliges all residents of Quebec to send their children to school in the francophone system. Exceptions to the law are made for the children of parents, at least one of whom attended school in Quebec in English, and for the children of parents living in Quebec only temporarily. The most significant change came, however, with the adoption at the end of the 1990's of changes to the educational system which replaced the existing 
confessionally based school boards (Catholic and Protestant) with linguistically based boards (French and English). At present, the majority of newcomers to Quebec send their children to school in French. The most recent information indicates that more than $80 \%$ of immigrants to Quebec choose to live in the Montreal region. Of the 500 , 000 immigrants living in Montreal, more than 100, 000 have arrived since 1996. The five most common countries of origin in this wave of immigration are Algeria (9\%), China (8\%), France (7\%), Haiti (5\%), and Morocco (5\%). Immigrant students are not divided equally among the different parts of the school system's territory. Some school have primarily, (or at least in part), immigrant populations, while others are populated almost exclusively by francophone or anglophone Quebecers. Multi-ethnic schools are often among the most underprivileged schools in the system, which seems to have increased over the last ten years. (McAndrew, 2001).

Unlike the Canadian policy of multiculturalism, Quebec has opted for an intercultural model based on a moral contract in which French is the common language of public life. This contract reiterates the democratic aspect of Quebec society, whereby the participation and contribution of every citizen is promoted within a framework of respect for democratic values and exchanges between the various communities (Gagnon, 2000). In order to encourage the scholastic integration of immigrant students and to prepare all students «...to participate in the building of a democratic, francophone and pluralistic Quebec», (MEQ, 1998, p.2, free translation) Quebec has developed a model of intercultural education which designates:

every educational undertaking aims to raise an awareness of the diversity, especially ethnocultural, which characterizes the social fabric and to develop competence in communicating with people of varying backgrounds, as well as attitudes of openness, tolerance and solidarity (ibid)

The intention behind this concept puts emphasis on the fact that intercultural education must not be oriented only toward the transmission of knowledge about varying cultures, but more toward a greater understanding of culture in pluralistic societies. This kind of education also supposes that each individual is conscious of his or her own «...cultural membership and looks at his or her own socialization in order to move beyond prejudices related to otherness, in whatever form, and thus better communicate with the other.» (ibid). 


\section{Problem definition}

Cultural, religious, and linguistic diversity in Montreal schools is a reality with which the educational and university sectors must deal. Those universities which train teachers are specifically called upon by the Ministry of Education (MEQ, 2001) to adequately prepare future teachers for this aspect of the school milieu. The Ministère de l'Éducation du Québec (MEQ, 1998) mentions that universities must take this issue into account in all aspects of the theoretical and practical training of future teachers who will have eventually to prepare their students to live in a pluralistic world. Some of the abilities, knowledge and skills which, according to the MEQ, students will have to develop and acquire are:

«attitudes of openness to diversity; pedagogical skills for working in a multiethnic milieu; competencies for the efficient resolution of conflicts of norms and practices; the ability to transmit the values and knowledge relative to Quebec heritage; to communicate with allophone parents who may not have the same educational values or customs; and the ability to include pluralism in the educational project» (MEQ, 1998, p. 32, free translation).

As for art, it is specifically mentioned that the art history component should include a consideration of the works of Quebec artists of diverse origins. Art should also be associated with international and intercultural understanding. Recently, the Programme de formation de l'école québécoise (MEQ, 2001b) stipulates that the artistic disciplines constitute a manner in which students can know themselves, enter into a relationship with others and interact with their environment. By their natures, the arts encourage the development of skills which are transferable to other fields of learning. Berthelot (1990) tells us that the arts provide an excellent opportunity for openness to the world and for the consideration of ethnocultural diversity. Unfortunately, these good intentions have for the most part remained theoretical and have neither been translated into the practice of art teachers in schools, nor into a real reflection on the part of the universities responsible for the training of Visual and Media Arts teachers.

The teacher training offered to future visual arts specialists here at UQAM has, for several years, been the object of growing interest both within the discipline and within the teaching profession as a whole. In spite of efforts to improve our training programme, I acknowledge that we know little of the relationship between the student and culture, either as student/artist or as culture-bearing-individual who will have to 
come to terms with the cultures of his or her students. The reforms brought to our Visual and Media arts teacher training program since 1977 include an increase in the time devoted to practical training, from 200 to 700 hours, with a view to establishing better connections between theory, practice and the realities of the field.

In my capacity as Pre-service supervisor at UQAM over the last ten years I have come to see that there is little interest on the part of the Student Teachers for questions related to the multiculturalism of the groups and classes which they were teaching. What is more, I noted a certain uneasiness and awkwardness in their dealings with this aspect of school life. At present, students must take a course in didactics of multiethnic classes in addition to their training within their chosen discipline. The content of this course is not related to the arts and does not necessarily figure in our training program. At this time we do not have any information regarding the impact of this course on the development of intercultural skills by students enrolled in our program,.

\section{Research Project Objectives}

The present study concerns the student teacher of visual and media arts wishing to teach art in a school context characterized by ethnocultural diversity. Developing a sensitivity and an interest for the teaching of art in a multicultural school context, that is to say to take the other into account in one's teaching, approaches and course content to facilitate the integration of students who are newcomers to Quebec society, is not only related to the acquisition of knowledge. Consequently, this study hopes to outline the attitudes, values, knowledge and representations of students in Visual and Media Arts Education, and who are orienting their practice toward the context of the multicultural school.

\section{Theoretical Framework}

As Lemerise (1998) reminds us, for a large part of the twentieth century, the teaching of art was conditioned by a growing interest in children's art and the birth of the child's creative faculties. For Lemerise, modernism in art education is generally associated with the arrival of a pedagogy centered on psychological theories of childhood development and on the appropriation of twentieth-century artistic codes and values. As is the case in other disciplines, artistic practices of the 1970's 
underwent major transformations, including a redefinition of the methods and the intentions of art. These changes appeared in the choice of materials, in the multiplication of unofficial exhibition spaces, in the blurring of boundaries between artistic disciplines, in a widening of the means of expression to include photography, the computer and multimedia, and in a return to figuration and a borrowing from art historical traditions (Lemerise, 1998). These upheavals shook our accepted ideas about art, the notion of individual creation, of originality, permanence and the relationship between the work and the spectator. What is more, certain claims made by feminist and minority culture groups had echoes in the worlds of art and art education which had until then ignored the artistic expressions of women and members of non-Western cultures.

The studies in art education which I consulted demonstrate that a multicultural perspective causes us to modify our view of art education and upsets certain cherished ideas of modernism, such as individualism, the emphasis on personal expression and on the authentic image, an intuitive knowledge of the world and the distinct division of disciplines (Richard, 1988). Efland (1990) tells us that in postmodern teaching the notion of art-for-art's-sake is replaced by the idea that works of art and the ideas which support them, are related to one another, as well as to the culture and the society from which they spring. The myth of art as a universal language which might be understood by all through western models, is brought into question by numerous authors considering art education in a pluralistic society. Beyond certain fundamental preoccupations with the contents of art and which among them to promote and to adapt to the classroom, research in the field of teacher training has mainly focused on the individual teacher who is at the heart of art teaching in an intercultural perspective. From this point of view, teacher training should pay special attention to the attitudes of teachers who, as we might guess, are, in large part, products of the ways in which they were trained at university, but doubtless also of the ways in which they perceive both the Other and their educational discipline in a multicultural school context. Consequently, the transmission of knowledge, the sensitization to the importance of including the Other in course contents would be insufficient without the emotional commitment of teachers (Ghosh, 1991). This commitment on the part of the teacher implies self-knowledge. Ghosh suggests that to understand oneself, through processes of introspective consideration of one's values, beliefs and attitudes, is the foundation for understanding others. The next level is an understanding of one's own culture compared to others. Intercultural 
education is based on an essential principle that the Other is at once identical to oneself and different from oneself. If one, or the other, of these two terms is missing, one is inevitably projected toward a teaching of exclusion (Abdallah-Pretceille, 1996). Others such as Belkaid (2000) underline the importance, for the teacher, of recognizing cultural diversity in him or herself, and in some cases to accept the absence of an individual identity. This experience, according to Belkaid, allows the teacher the experience of de-centring, to step back from oneself while remaining close to one's own experience. She suggests that if we teach what we are, then it is probably useful for every teacher to know who he or she is, insofar as that is possible.

Apart from this introspective look at oneself and one's own culture, Ouellet (2002), identifies certain theoretical reference points which allow us to situate cultural pluralism in a wider perspective. The reference points imply, among other things, an awareness of culture, ethnicity and identity in a modern and post-modern context, an understanding of prejudices, of discrimination and racism as obstacles to intercultural relationships, and an awareness of methods of integrating immigrants into contemporary societies.

Consequently the study focuses on the teacher as an individual with a specific cultural background, and as a cultural mediator in his/her professional commitment in multicultural settings.

\section{Research Methods}

Within the framework of this study I have employed a qualitative descriptive research approach. Through individual, semi-directed interviews I collected from thirty student volunteers, each finishing their third or fourth year of a Bachelor's degree in Education in the Visual and Media Arts, comments with a view to obtaining information on their perceptions, their affective states, their judgments, opinions and representations according to their frames of reference and concerning current situations (Van der Maren, 1996). As such, the study investigates the meanings given by students to the notions of culture and cultural identity, to the beliefs and values concerning the teaching of art in schools and particularly, in a multicultural school context. The meanings given by the participants to these different aspects are based on their personal experiences of ethnocultural diversity and on their pedagogical practice in the multicultural school context. More specifically the interview was divided along four themes: 


\section{Culture and cultural identity:}

1.1 How would you describe the culture in which you grew up?

1.2 How different is your present cultural identity from what you described in question 1 ?

\section{Personal experience of cultural diversity:}

2.1 What personal experience, else than professional exposure, do you have of cultural diversity?

\section{Beliefs, values and references concerning art teaching:}

3.1 What is your personal conception of art teaching?

3.2 To what type of documentation do you refer yourself in the preparation of your art courses?

\section{Teaching experience in multicultural settings:}

4.1 Comments on your personal experience of teaching in multicultural classes?

4.2 How did you adapt your teaching to the cultural diversity of your classes?

4.3 How did the teacher who supervised you adapt his teaching to the cultural diversity of the classes?

4.4 Give an example of a course you would like to give that would take into account the cultural diversity? That would help students from diverse ethnocultural background to understand Quebec's culture?

4.5 Do you feel you have the proper training to teach in multicultural settings?

\section{The Sample}

The majority of the students who participated in the study are women (26) with an average age of 25. They are mainly of francophone-québecois origin and for the majority they did not grow up In the city of Montreal. This last point is particularly interesting for my study since the phenomenon of immigration is primarily concentrated in Montreal.

\section{Conclusion}

This study, when it is done, will allow us to improve the training of visual and media arts teachers and to build interest in the school and university milieus for the development of pedagogical and research projects in this field. It seems a necessity that we should be able to guarantee a training for our future teachers which equips 
them to deal with this dimension of the educational system and to teach the visual arts from a diversified and inclusive point of view. Today's visual arts education students will be tomorrow's art teachers. They will have to make choices daily concerning the content of their teaching, they will have to engage their students in meaningful learning, to react when facing discrimination or inter-ethnic tensions, and to deal with values and cultural traditions fundamentally distanced from their own. Visual and media arts education students must realize that the teaching of art is more and more pluralistic endeavour and constitutes an open door on the world of today.

\section{BIBLIOGRAPHIE}

Abdallah-Pretceille.M., Porcher, L. 1996. Éducation et communication interculturelle. Paris : Presses universitaires de France.

Belkaïd, M. 2000. «La diversité culturelle : pour une formation des enseignants en altérité» in Raisons éducatives Pourquoi des approches interculturelles en science de l'éducation? p..205-222. Genève : De Boeck Université : Genève.

Berthelot, J. 1990. Vivre et auvrer dans un Québec pluriethnique et français. Pour que fleurisse le changement. $32^{\mathrm{e}}$ Congrès, Centrale de l'enseignement du Québec, Centre Sheraton Laval. p.24-30.

Efland, Arthur. 1995. «Change in the Conceptions of Art Teaching»., Context, Content and Community in Art Education, Beyond Postmodernism., Edited by Ronald W. Neperud, Teachers College Press.

Gagnon, Alain-G. 2000. «Playdoyer pour l'interculturalisme»., Possibles

Interculturalisme québécois., Vol. 24, Numéro 4., automne, p.11-25.

Ghosh, R. 1991., "L'éducation des maîtres pour une société multiculturelle» in F. Ouellet et M. Pagé (dir) Pluralisme, Éducation et Société construire un espace commun ., p.207229. Québec : Institut québécois de recherche sur la culture.

Gouvernement du Québec, MEQ. 1998. Une école d'avenir. Intégration scolaire et éducation interculturelle, Éd. Officiel du ministère de l'Éducation..

Gouvernement du Québec, MEQ. 2001a. La formation à l'enseignement Les orientations Les compétences professionnelles. Ministère de l'Éducation.

Gouvernement du Québec, MEQ. 2001b. Programme de formation de l'école québécoise ; éducation préscolaire et enseignement primaire, Québec, Éd. Officiel du Québec, ministère de l'éducation. 
Lemerise S. 1998. "Le flou des catégories dans le foisonnement des pratiques Du modernisme au postmodernisme au Québec : repères historiques». Dans M. Richard et $\mathrm{S}$. Lemerise (dir) Les arts plastiques à l'école. Les Éditions Logiques : Montréal. P. 17-49.

Mc Andrew. M. 2001. Immigration et diversité à l'école. Le débat québécois dans une perspective comparative. Québec : Les presses de l'université de Montréal.

Ouellet, F. 2002. Les défis du pluralisme en éducation., Les presses de l'Université Laval :Québec.

Richard, M. 1994. Postmodenisme, pli baroque et pédagogie nomade : analyse de trois projets artistiques de réappropriation ludique du corps et de l'espace avec les enfants. Thèse (phd). Montréal : Université Concordia.

Van der Maren, J-M.1996. Méthodes de recherche en éducation. Les Presses de l'Université de Montréal De Boeck Université. 
